\title{
Analysis of Nutritional Status of School Children in Ayagama
}

By

KATHRI ARACHCHIGE NIROSHA THARANGANIE

Thesis submitted to the University of Sri Jayewardenepura in partial fulfillment requirement for the award of the degree of Master of Science in Food Science and Technology on 22.09.2008 


\section{DECLARATION}

"The work described in this thesis was carried out by me under the supervision of Prof. Authur Bamunuarchchi and Dr. K.K.D.S. Ranaweera, and a report on this has not been submitted in whole or in part to any university or any other institution for another Degree/ diploma"

....06:07. 2009

Date

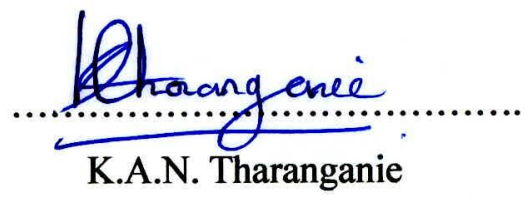


I certify that the above statement made by the candidate is true and that this thesis is suitable for submission to the University for the purpose of evaluation"

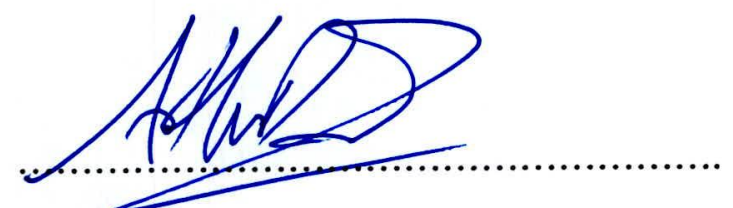

Signature

Supervisor

Prof.Authur Bamunuarchchi

Former Head/ Department of Food Science and Technology

University of Sri Jayawardanapura

Sri Lanka 


\section{TABLE OF CONTENTS}

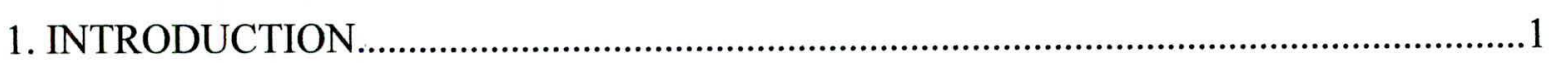

1.1 Study Area

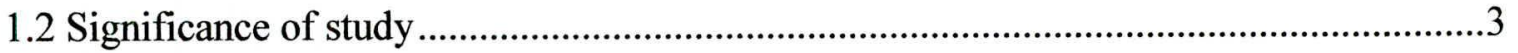

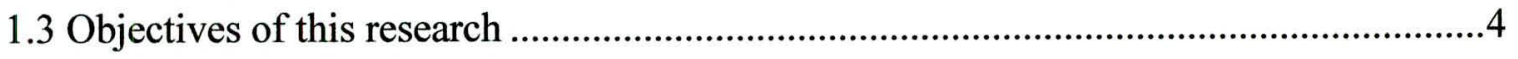

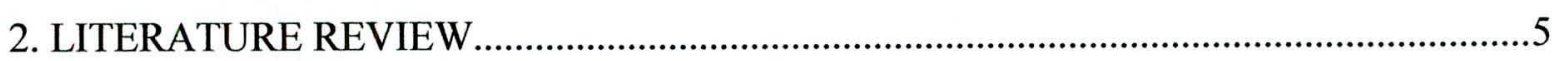

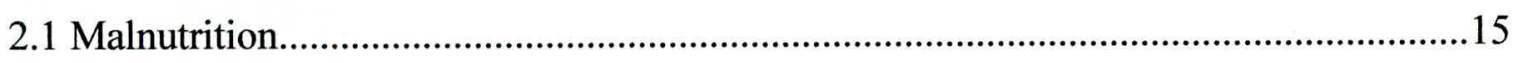

2.3 Recommended Dietary Allowances (RDA) ……………...........................................16

2.4 Body Mass Index......................................................................................................17

2.5 Importance of Nutrition - School children ....................................................................17

2.6 Nutrient Components in Diet ....................................................................................18

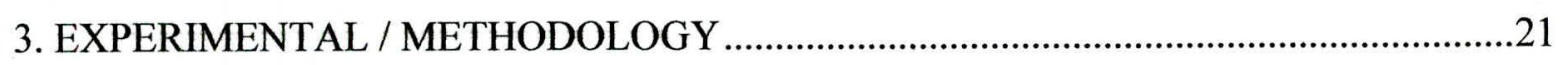

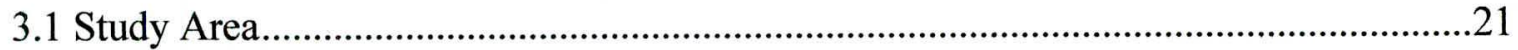

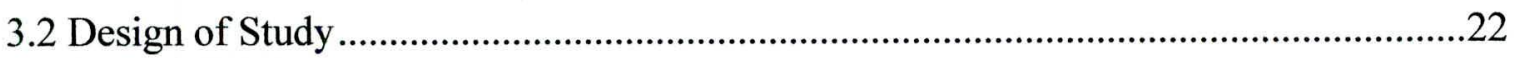

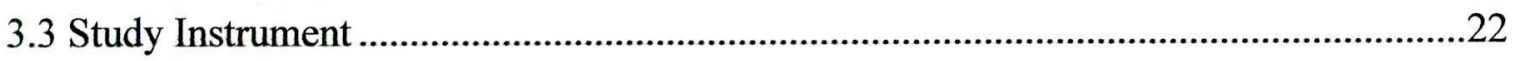

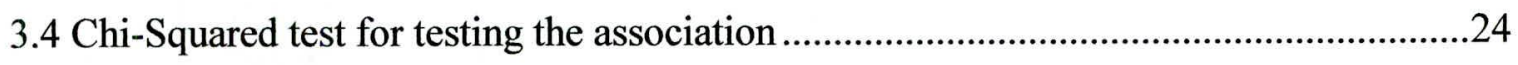

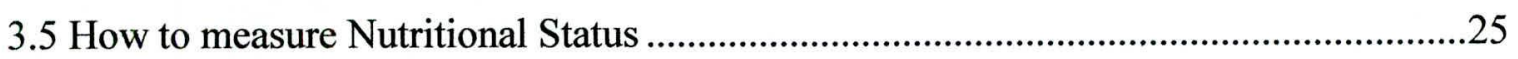

4. RESULTS \& DISCUSSION .......................................................................................26

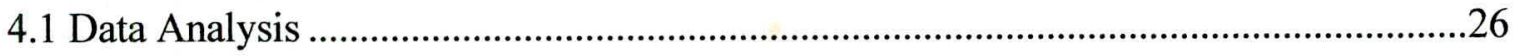

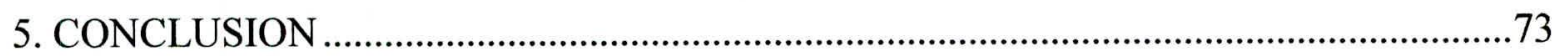

6. REFERENCES

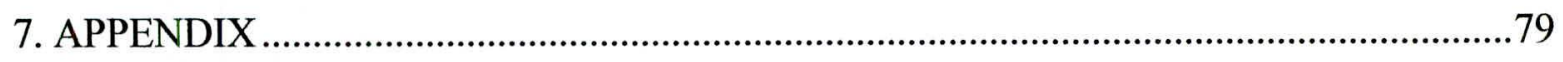

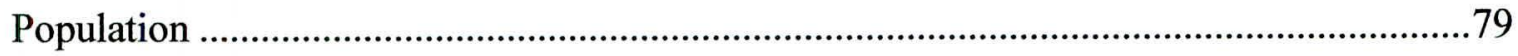

Water Supply

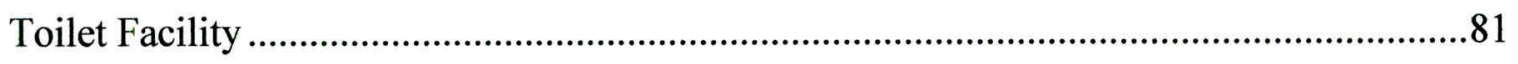

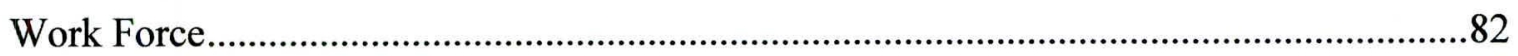

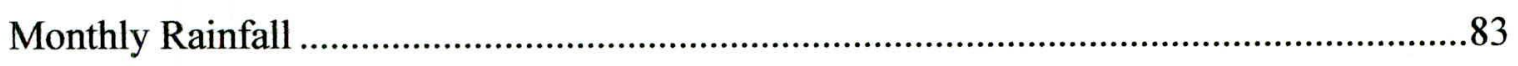

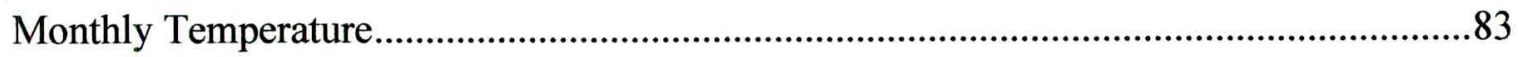

Total Children in Schools..........................................................................................8

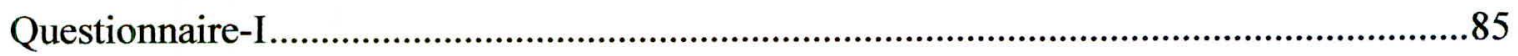

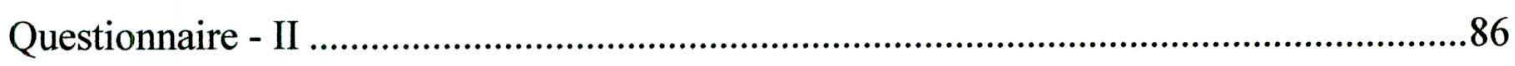

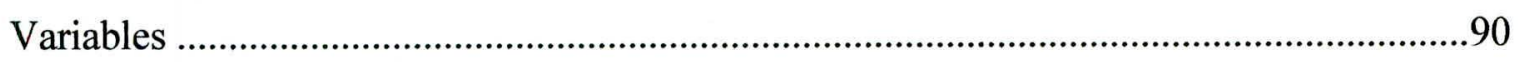

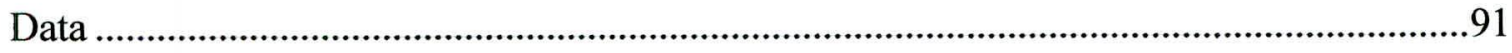




\section{LIST OF TABLES}

Table 4.1: Students in Grade Six, Seven and Eight .............................................................. 26

Table 4.2: Students in Galathura, Gavaragiriya, Pibura ........................................................... 27

Table 4.3: Percentages of students according to their Grade and School................................ 27

Table 4.4: Male and Female Students................................................................................... 27

Table 4.5: Percentages of students (Sex, School and Grade) .............................................28

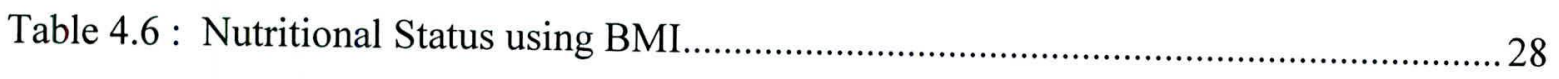

Table 4.7: Percentages of students (Sex and Nutritional Status) .............................................29

Table 4.8 : Percentages of students (Sex, School and Nutritional Status)............................... 31

Table 4. 9 : Percentages of students (School and Nutritional Status) ........................................ 32

Table 4.10: Frequency table for student's breakfast............................................................... 33

Table 4.11: Frequency table for student's snacks ( school interval time) ................................35

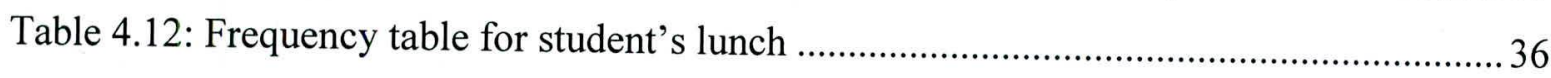

Table 4.13: Frequency table for student's dinner .................................................................. 37

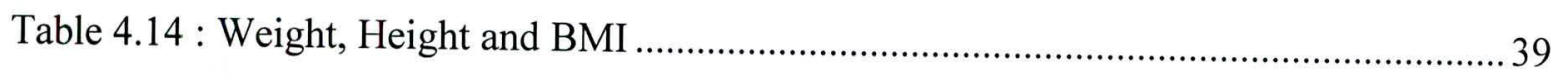

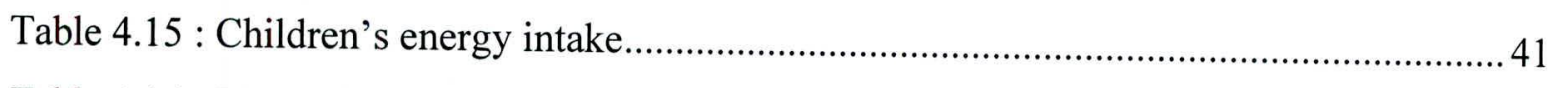

Table 4.16 : RDA ( Recommended Dietary Allowances) ...................................................... 42

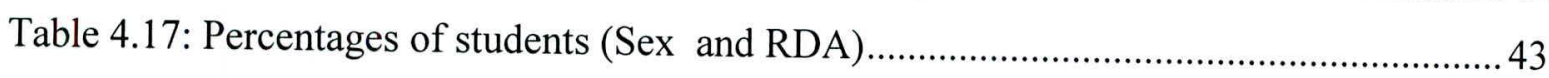

Table 4.18: Contingency table for Age and Nutritional Status ................................................4 44

Table 4.19: Chi-Square Tests (Age and Nutritional Status) ................................................... 44

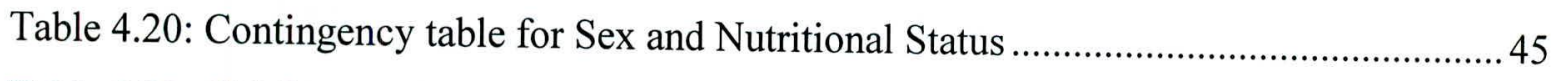

Table 4.21: Chi-Square Tests (Sex and Nutritional Status)................................................... 45

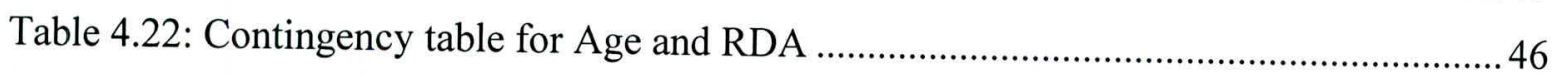

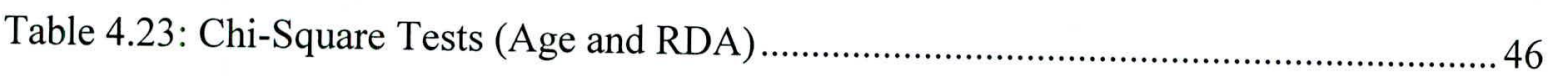

Table 4.24: Contingency table for Sex and RDA .................................................................. 47

Table 4.25: Chi-Square Tests (Sex and RDA ) ...................................................................... 47

Table 4.26 : Percentages of students (Race and Nutritional Status) ........................................ 48

Table 4.27 : Percentages of students (Religion and Nutritional Status) ................................. 49

Table 4. 28 : Percentages of students (Father's Education Level and Nutritional Status)....... 50

Table 4.29 : Percentages of students (Mother's Education Level and Nutritional Status) .......51

Table 4.30 : Percentages of students (Father's Employment Status and Nutritional Status)... 52

Table 4.31 : Percentages of students (Mother's Employment Status and Nutritional Status) .53

Table 4.32 : Percentages of students (Employment Type of Father and Nutritional Status ) .54

Table 4.33 : Percentages of students (Employment Type of Mother and Nutritional Status). 55 
Table 4.34 : Percentages of students (Dwelling Place and Nutritional Status) ....................... 56

Table 4.35 : Percentages of students (Type of Wall and Nutritional Status) ...........................57

Table 4.36 : Percentages of students (Source of Drinking Water and Nutritional Status) ...... 58

Table 4.37 : Percentages of students (Toilet Availability and Nutritional Status) ....................58

Table 4.38 : Percentages of Students (Toilet Type and Nutritional Status) .............................59

Table 4.39 : Percentages of Students (Source of Light and Nutritional Status) .......................60

Table 4.40 : Percentages of Students (Source of Cooking Fuel and Nutritional Status).........61

Table 4. 41 : Percentages of Students (Condition of House and Nutritional Status)................6 62

Table 4. 42 : Percentages of Students (Benefits and Nutritional Status) ..................................6 62

Table 4. 43 : Percentages of Students (Number of Dependents and Nutritional Status) ......... 63

Table 4.44 : Percentages of Students (Income Category and Nutritional Status) .....................6 64

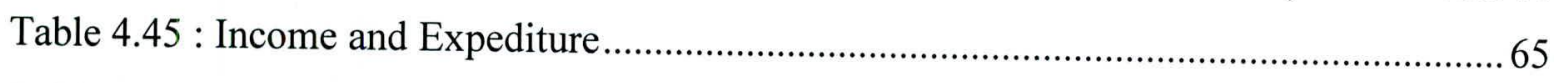

Table 4.46 : Contingency table for Income Category and Nutritional Status .........................66 66

Table 4.47: Chi-Square Tests (Income Category and Nutritional Status) ...............................6. 66

Table 4.48 : Contingency table for Number of Dependants and Nutritional Status................67

Table 4. 49: Chi-Square Tests (Number of Dependents And Nutritional Status) .................... 68

Table 4.50: Contingency table for Toilet Availability and Nutritional Status ........................69

Table 4.51: Chi-Square Tests(Availability of Toilet And Nutritional Status)......................... 70

Table 4.52: Contingency table for Source of drinking water and Nutritional Status .............. 71

Table 4.53: Chi-Square Tests(Source of drinking water And Nutritional Status)................... 71 


\section{LIST OF FIGURES}

Figure 4.1: Nutritional Status of School Children .29

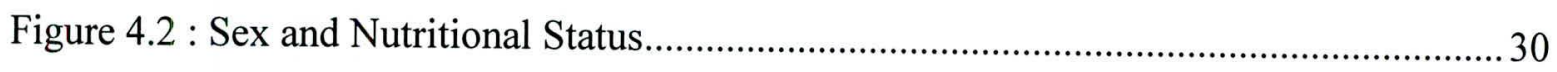

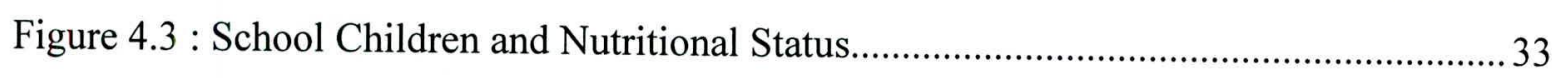

Figure 4.4 : Histogram for school children's breakfast ......................................................... 34

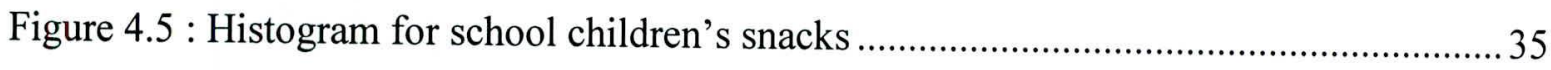

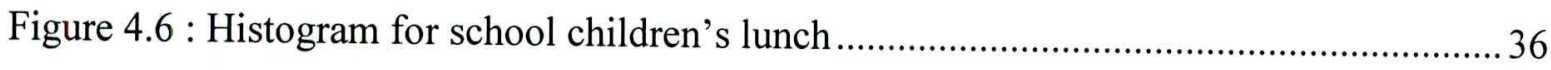

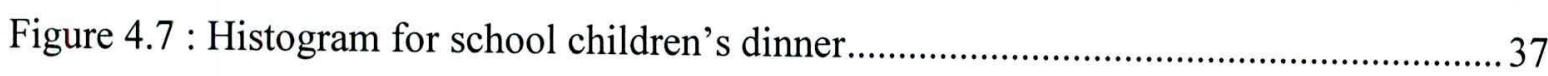

Figure 4.8 : Histogram for school children's weight .............................................................. 40

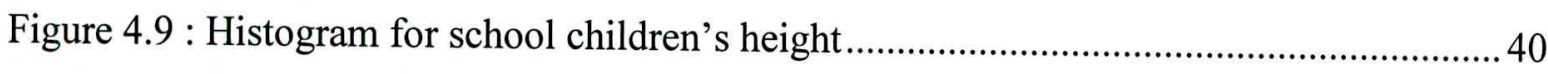

Figure 4.10 : Histogram for school children's BMI .............................................................. 41

Figure 4. 11 : Histogram for school children's energy intake ................................................ 42

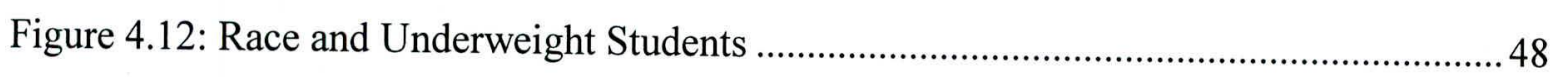

Figure 4.13 : Religion and Underweight students ................................................................ 49

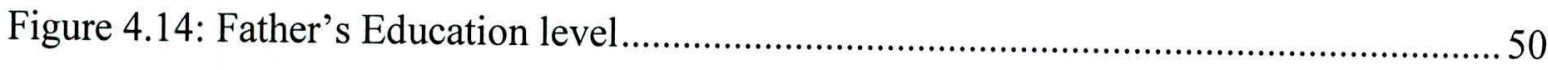

Figure 4.15 : Mother's Education Level ............................................................................... 51

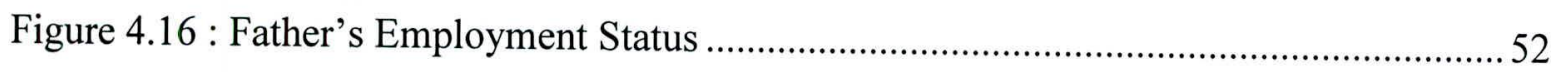

Figure 4.17 : Mother's Employment Status............................................................................ 53

Figure 4.18 : Employment Type of Father …......................................................................... 54

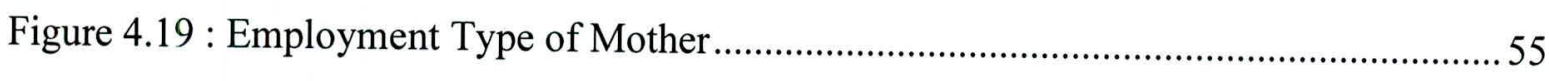

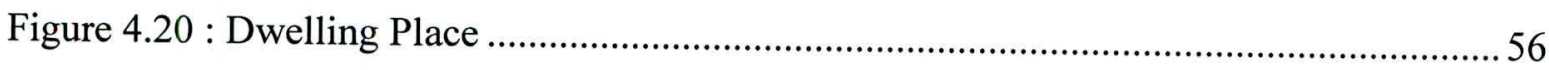

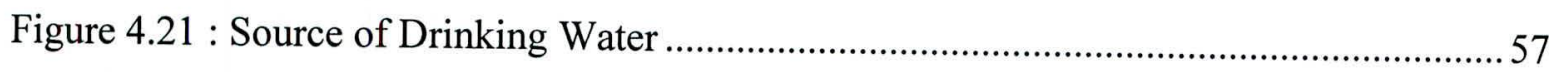

Figure 4.22 : Safe and Unsafe Drinking Water .................................................................... 58

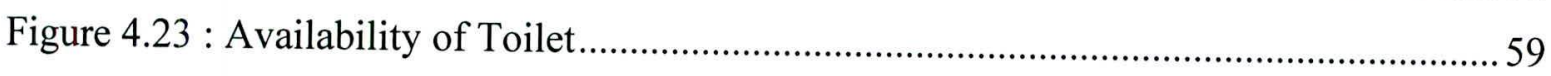

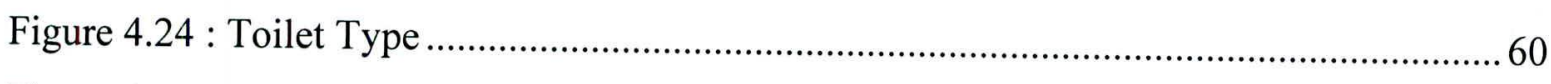

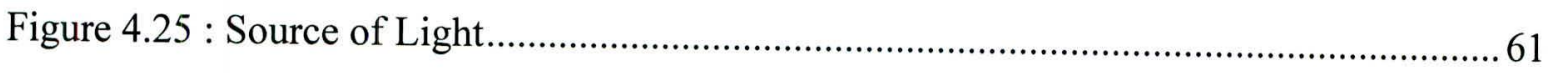

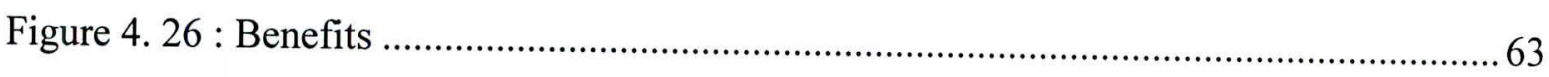

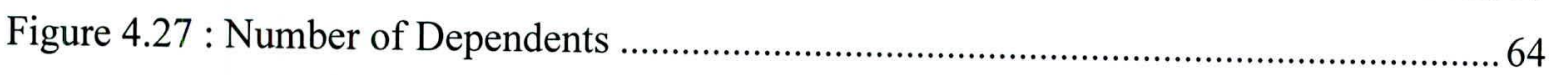

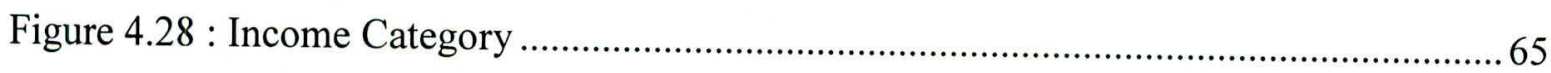




\section{ACKNOWLEDGEMENT}

I wish to express my sincere thanks and heart felt gratitude to my supervisors Prof. Aurthur Bamunuarachchi, and Dr. K.K.D.S. Ranaweera, Head/Department of Food Science and Technology of University of Sri Jayawardanapura.

I Also thankful to Mr.P. Kodithuwakku, Chief Secretary of Sabaragamuwa Province, who gave me valuable instructions and support to complete this thesis.

I would like to thank Mr. Chamara Bamunusinghe, Divisional Secretory of Ayagama, and Mrs. Tharaka Dissanayaka, Assistant Divisional Secretory who gave me guidance in several ways to success this project.

I would like to thank principles of Galatura Vidyalaya, Gavaragiriya Maha Vidyalaya, and Pibura Vidyalaya for assistance given to me in several ways in during the period of this survey.

I wish to express my sincere gratitude with deep appreciation to my husband and my dearest parents for their fullest cooperation given to me to pursue this study. There are numerous others whose name through not mentioned to whom thanks are due. 


\title{
Analysis of Nutritional Status of School Children in Ayagama By K.A.N. Tharanganie
}

\begin{abstract}
The present study was carried out to ascertain the nutritional status of school children in Ayagama in the Sabaragamuwa Province.
\end{abstract}

The procedure consists of interacting with children, parents and school teachers in a randomly selected sample using a prepared questionnaire where the questions were targeted to collected relevant information.

A total of 150 students were interacted with in the period of two weeks to gather information in their food consumption pattern. Data related to socio economic status of the families were collected from parents assisted by the teachers. The data obtained were subjected to analysis by statistical methodologies such as descriptive analysis, Chi-squared testing and other statistical significance testing.

Study revealed that $71 \%$ of school children in Ayagama were malnourished and rest of them were in normal nutritional level. There were no obese students in this area. From boys, 77.8\% of were malnourished and $22.2 \%$ were nourished, while from girls $62.3 \%$ were malnourished and $31.7 \%$ were nourished. Age, Sex, RDA, Mother's education level, Mother's employment status, Source of drinking water, Number of dependents were identified as the major affecting factors for the Nutritional status of school children in Ayagama.

The minimum and maximum of BMI distribution were recorded as $10.89 \mathrm{~kg} / \mathrm{m}^{2}$ and $21.63 \mathrm{~kg} / \mathrm{m}^{2}$ respectively. The average value of school children's BMI was $14.59 \mathrm{~kg} / \mathrm{m}^{2}$, and the standard deviation was $2.40 \mathrm{~kg} / \mathrm{m}^{2}$.

Study reveals that poor education of parents, their work status (about $63 \%$ state labours), income level directly affected to the nutritional status of the children. Baseline results demonstrated, that more children were malnourish than normal. 


\section{INTRODUCTION}

Nutrition is one of the main basic requirements for human life. Nutrition is about food and how it affects our health. It includes how the body digests food and uses the nourishment and excrement of waste through urine or bowel movements. Different people and different age groups need different food.

Schooling age of children is between 6-18 years of old. The food pattern is very essential in this age and it is found to be that the food pattern during this age is the main influence on the children's daily energy and nutrient intake. Breakfast and snacks are to be relatively greater importance meal as a source of energy and nutrient because children activities are too high in their schooling time.

Poor nutrition in school children is known to compromise their health and learning capacity and healthy children lean things more easily. Good nutrition maintains the current nutritional status of young people as well helping to prevent the onset of future health problems.

Nutrition status of children directly depend on food style and indirectly depend on family size, work status of parents, type of dwelling place, source of drinking water, type of latrine, education level of mother, some other factors like environment (natural) disasters ( eg. floods, heavy rain fall, landslides,...), because they cause to water born diseases.

Schoolaged children are still growing. Growth requirements combined with physical activity play a role in determining a child's nutritional needs. Genetic background, gender, and body size and shape are other factors. The nutrients needed by children are same as for adult but the amounts vary.

Carbohydrates and fats provide energy for growing and physical activity. Through the school years children will hit periods of rapid growth. During those times, appetites expand. When growth slows, appetites diminish and children will eat less food at meal times. Protein builds, maintains and repairs body tissue. It is especially important for growth. 
If school children fail to get all the nutrients they need, this is called malnutrition and insufficient food energy causing starvation, this is called undernutrition. So we have to pay special attention for identify nutritional problems with related to their food habits.

\subsection{Study Area}

Ayagama secretarial division is located at Rathnapura district in Sabaragamuwa province. Among all secretarial divisions in Rathnapura district, Ayagama is one of the most underprivileged, remote secretarial division. Its area is about 151 square kilometers (15170ha) and contains 21 Grama Niladari divisions and 76 villages. Throughout secretarial divisions in Rathnapura district Ayagama is a most difficult area. Mainly agrarian region special crops are tea and rubber.Very suitable climatic condition has in this are for agricultural purposes. Fruits and vegetables mostly come from the out side, but large scale agriculture farms are not established, Fish and dry fish come from costal area but fresh fish are not freely available in market but poultry products are available. Multi national communities can be seen and they are mainly Singhalese and Tamil living together.

According to the statistics from "Sampath Pathikada" done by Muthunayaka, the mean annul rainfall is over $3000 \mathrm{~mm}$. Heavy rain falls during the south-west monsoon that runs between May and September. The mean annual temperature range is between $26.8 \mathrm{C}$ to $28.6 \mathrm{C}$ and average temperature is $25.5 \mathrm{C}$, and February and March are the warmest months. Natural disasters like floods and landslides are common in this division. Generally, total population of the area is about 261.26 per 1 square $\mathrm{Km}$ and $53 \%$ of the total populations live in Galatura, Singhalagoda, Ayagama, Katepola because these villages located near the bus road.

Education: According to the information obtained from Gramaniladari regarding education in 2006 , about $16.75 \%$ of people passed grade eight, $7.63 \%$ of people passed G.C.E(O/L), $2.71 \%$ passed G.C.E (A/L) and $0.16 \%$ of people are graduates.

Work force: Throughout the total population, about $63.33 \%$ families are state laborers, $5.6 \%$ doing government jobs, $16.40 \%$ doing non-government jobs, about $1.154 \%$ doing foreign jobs, about $13.43 \%$ doing self employments. 
Source of drinking water: They use water for bathing, drinking and washing by water falls, tube wells, gutter, ponds, cannels, uncovered wells or wells rather than pipe bone water. There are about $12.8 \%$ unsafe wells in this area. (See the Appendix)

Sanitary facilities: Usages of toilets among the people in this area are water sealed latrines, pit latrines and absence of toilets. As a percentage, about $80.99 \%$ families have water sealed latrines, and about $13.1 \%$ families have pit latrines and $5.9 \%$ families do not have toilets in total population. (See the Appendix)

Monthly income: Less than $25 \%$ of families obtain about Rs 7,500 as a monthly income while More than $75 \%$ of families in this area obtain about Rs1,500 and among them $62 \%$ families got Samurdhi benefits. (See the Appendix)

Education: There are 25 schools in this area and contain one central college. 4649 children are study these schools. 92 female children and 188 male children in schooling age whose are not entered the school. (See the Appendix)

\subsection{Significance of study}

There have been a number of studies in recent years into the dietary habits of school children in urban areas but relatively little work on school-children in rural areas which are specially located in natural disaster zones in Sri Lanka. This study was conducted to find the nutritional status of school children (11-13 year-olds) in Ayagama Secretarial Division in Rathnapura District. Because, it is a one of the most underprivileged, remote secretarial division. This area has many geographical barriers, due to poor transportation facilities, health facilities and flood in several times in every year as a results occurrence of different health problems like chikun-gunya, dengue, diarrhoea etc. The research also examined the relative importance to total energy and nutrient intake of food provided at home, breakfast, snacks, lunch and dinner additionally whether there were any differences between dietary intakes, heights and weights of children and number of dependence in the family, parent's income, maternal education level, source of drinking water, toilet facilities, maternal sanitary practices from various socio-economic backgrounds. 


\subsection{Objectives of this research}

1. To identify information on the nutritional status of 11-13 years of age school children in Ayagama Secretarial Division.

2. To find the affecting factors (socio-economic parameters) for the nutritional status of school children.

3. To find the energy intake status of school children.

4. Examine the relationship between the selected variables and the incidence of under nutrition.

5. Use small area estimation methods to estimate under nutrition state of Ayagama. 


\section{LITERATURE REVIEW}

Hettiarachchi, M et al (2006) carried out on nutrient intake and growth of adolescents in Southern Sri Lanka. It showed that $21.3 \%$ of boys and $21.1 \%$ of girls were stunted $(14.9 \%)$ children were both stunted and wasted. Mean body mass index of girls was significantly higher than boys at all ages. High rate of growth deficiency and under nutrition among adolescents mandates innovative nutritional intervention strategies.

Department of Nutrition, Medical Research Institute Colombo carried out on Prevalence of challenging Nutritional problems among adolescents in Sri Lanka. The prevalence rates of underweight, stunting, and overweight were $47.2 \%, 28.5 \%$, and $2.2 \%$, respectively. The prevalence rates of anemia and vitamin A deficiency were $11.1 \%$ and $0.4 \%$, respectively. During the previous 6 months, $10.4 \%$ of the subjects had usually not eaten breakfast before going to school. During the week before the interview, $24.4 \%$ of the children had not consumed green leafy vegetables, $26.6 \%$ had not consumed fruit, $19.0 \%$ had not participated in physical activities, and $27.5 \%$ had watched television for more than 2 hours per day. The nutritional problems of adolescents aged 10 to 15 years should be addressed through the schools. Specific policies should be developed in collaboration with the Ministry of Health and Education to control nutritional problems among adolescents. (Jayatissa \& Ranbanda 2006)

Dietary survey done by Wickramasinghe,VP et al (2004) of Seven schools situated in the city of Colombo were randomly selected. They showed a fair representation of children of all social levels. Anthropometric data of 1224 children (48\% boys), and feeding practices and behaviour pattern data of 1102 children (44\% boys) were analysed. Obesity prevalence among boys (4.3\%) was higher than in girls (3.1\%). The prevalence of thinness was $24.7 \%$ in boys and $23.1 \%$ in girls. $5.1 \%$ of boys and $5.2 \%$ of girls were stunted. $7.0 \%$ of boys and $6.8 \%$ of girls were underweight. $66 \%$ of obese children and $43.5 \%$ of overweight children belonged to high-income category (monthly family income more than Rs. 20,000). Apart from family income, behaviour patterns did not significantly influence the nutritional status. Although the data are not representative of the entire country, nutritional transition is evident in the city of Colombo. Obesity and overweight in older children are some emerging nutritional problems 
that may be the consequence of emerging patterns of the lifestyle and diet in response to social and cultural changes. (Wickramasinghe et al, 2004)

Department of Biochemistry Faculty of Medicine University of Colombo carried out Iron status of adolescent females in three schools in un urban area of Sri Lanka.Ninety-three females in the age group 14-18 years were randomly selected from three schools in Colombo. Their iron and nutritional status was assessed using clinical, anthropometric, haematological, and biochemical parameters. Haemoglobin levels less than $12 \mathrm{~g} / \mathrm{dl}$ were seen in 3.7 per cent of adolescent females. Free erythrocyte protoporphyrin levels greater than 70 micrograms/dl and serum percentage transferrin saturation values less than 16 per cent indicate iron deficiency and were seen in 10 per cent and 14 per cent of the subjects, respectively. Serum ferritin levels less than 12 micrograms/l indicate depleted iron stores and were seen in 59 per cent of the subjects studied. Our results suggest that although overt anaemia was not common among the subjects studied, a large number of subjects belonging to the lower socioeconomic groups were in the early stages of iron deficiency and had depleted iron stores. These subjects are, therefore, at risk of developing clinical manifestations of iron deficiency when the demand for iron is increased, as in pregnancy. (Atukorala \& DeSilva 1990)

Nestel et al (2004) carried out on the use of iron-fortified wheat flour to reduce anemia among estate population in Sri Lanka. The use of flour fortified with $66 \mathrm{mg} / \mathrm{kg}$ of electrolytic or reduced iron to reduce the prevalence of anemia was determined in a two-year, doubleblind, controlled trial. The trial was conducted in Sri Lanka among preschoolers between 9 and 71 months old, primary schoolers 6 to 11 years old, and nonpregnant women. At baseline, $18.4 \%$ of the preschoolers had low hemoglobin $(\mathrm{Hb})$ concentrations. Neither electrolytic nor reduced iron had an effect on $\mathrm{Hb}$ concentration among preschoolers. Only $7 \%$ of the primary schoolers were anemic at the start of the trial and, again, fortification had no effect on $\mathrm{Hb}$ concentration. Twenty-nine percent of women had a low $\mathrm{Hb}$ at outset and there was no evidence that fortification had an effect on $\mathrm{Hb}$ in this group. The findings from this study suggest that fortification of flour with electrolytic iron or reduced iron was not beneficial in reducing anemia in this population. This was probably due to the low prevalence of anemia and low bioavailability of the fortificant iron. Fortification with either iron fortificant was acceptable.(Nestel et al 2004) 